\title{
Pleurone, a novel human neutrophil elastase inhibitor from the fruiting bodies of the mushroom Pleurotus eryngii var. ferulae
}

\author{
Ik-Soo Lee ${ }^{1,2}$, In-Ja Ryoo ${ }^{1}$, Kyong-Yeal Kwon ${ }^{3}$, Jong Seog Ahn ${ }^{1}$ and Ick-Dong Yoo ${ }^{1}$
}

The Journal of Antibiotics (2011) 64, 587-589; doi:10.1038/ja.2011.47; published online 15 June 2011

Keywords: human neutrophil elastase, kinetics; Pleurotaceae; Pleurotus eryngii var. ferulae

The genus Pleurotus (Jacq.: Fr.) Kumm. (Pleurotaceae, higher Basidiomycetes) comprises a diverse group of cultivated mushroom species with high nutritional value and significant pharmacological properties. In the past decade, compounds with medicinal properties, including antiviral, ${ }^{1}$ antitumor, ${ }^{2}$ antibacterial, ${ }^{3}$ antibiotic, ${ }^{4}$ anticholesterologenic ${ }^{5}$ or immunostimulatory ${ }^{6}$ effects, have been isolated from several Pleurotus spp. ${ }^{7}$ However, the constituents of Pleurotus eryngii var. ferulae, a mushroom popular in China for its flavor and high nutritive value, have not been thoroughly examined for their potential medicinal properties.

P. eryngii var. ferulae, the ferulae mushroom, grows on the medicinal plant Ferula assa-foetida in central China. A previous study revealed that a crude extract of $P$. eryngii var. ferulae has significant free-radical-scavenging, acetylcholinesterase-inhibitory and brain cell-protective effects. ${ }^{8}$ Recently, an ethanol (EtOH) extract of the fruiting bodies of P. eryngii var. ferulae was reported to show a strong antitumor activity against three human solid carcinomas, a lung carcinoma (A549) and two cervical carcinomas (SiHa and HeLa). ${ }^{9}$

In searching for novel, naturally occurring inhibitors of human neutrophil elastase (HNE), a serine protease found in the azurophilic granules of neutrophils, we found that the EtOAc-soluble fraction of a methanol $(\mathrm{MeOH})$ extract of $P$. eryngii var. ferulae sporocarps has considerable HNE-inhibitory activity $\left(\mathrm{IC}_{50}, 62.9 \mu \mathrm{g} \mathrm{ml}^{-1}\right.$ ). Further investigation of this fraction resulted in the isolation of one new compound (1), together with three known compounds (2-4). This report describes the isolation and structural elucidation of these compounds, as well as the characterization of their HNE-inhibitory effects.

The dried sporocarps of $P$. eryngii var. ferulae $(4 \mathrm{~kg}$, cultured in Cheonan, Korea) were extracted with $\mathrm{MeOH}$ (81) at room temperature for 7 days, filtered and concentrated to yield a $\mathrm{MeOH}$ extract $(110 \mathrm{~g})$. This extract was suspended in $\mathrm{H}_{2} \mathrm{O}(2 \mathrm{l})$ and then partitioned successively with $n$-hexane (3l) and ethyl acetate (EtOAc, $4 \mathrm{l}$ ) to yield $n$-hexane- and EtOAc-soluble fractions (20 and $8 \mathrm{~g}$, respectively). The EtOAc-soluble fraction, which significantly inhibited HNE, was subjected to chromatography on a silica gel column. Elution with a gradient solvent system consisting of $\mathrm{CH}_{2} \mathrm{Cl}_{2}-\mathrm{MeOH}(50: 1 \rightarrow 1: 1)$ yielded four fractions A-C. Fraction A $(1.1 \mathrm{~g})$ was applied to a silica gel column and eluted using $n$-hexane-acetone (10:1), yielding compound $2(25 \mathrm{mg})$. Fraction B $(0.8 \mathrm{~g})$ was applied to the same silica gel column and eluted using a hexane-acetone gradient solvent system $(10: 1 \rightarrow 5: 1)$, yielding compound $3(8 \mathrm{mg})$. Chromatography of fraction $\mathrm{C}(1.8 \mathrm{~g})$ on the silica gel column using a $\mathrm{CH}_{2} \mathrm{Cl}_{2}-\mathrm{MeOH}$ gradient solvent system $(10: 1 \rightarrow 1: 1)$ yielded four subfractions (C1-C4). Subfraction C2 (0.2 g) was further purified by preparative reverse phase-high-performance liquid chromatography on a YMCpack Pro $\mathrm{C}_{18}$ (YMC, Tokyo, Japan) $(250 \times 10 \mathrm{~mm})$ column (UV detection at $254 \mathrm{~nm})$ using $\mathrm{MeOH}-\mathrm{H}_{2} \mathrm{O}(20: 80, \mathrm{v} / \mathrm{v})$ at a flow rate of $2.0 \mathrm{ml} \mathrm{min}^{-1}$ as the mobile phase. This procedure yielded compounds $1(5 \mathrm{mg})$ and $4(4 \mathrm{mg})$ with retention times $\left(t_{\mathrm{R}}\right)$ of 6.5 and $5.2 \mathrm{~min}$, respectively.

Compound 1, designated 'pleurone', was obtained as an amorphous white powder with the following spectral characteristics: UV $(\mathrm{MeOH})$ $\lambda_{\max }(\log \varepsilon): 227 \mathrm{~nm}(3.2), 258 \mathrm{~nm}$ (3.8); IR (KBr) $v_{\max }: 1714$, $1654 \mathrm{~cm}^{-1} ;{ }^{1} \mathrm{H}-\mathrm{NMR}$ (400 MHz, dimethyl sulfoxide- $\left.d_{6}\right): \delta 5.44$ (d, $J=7.6 \mathrm{~Hz}, \mathrm{H}-3), 7.38$ (d, $J=7.6 \mathrm{~Hz}, \mathrm{H}-4$; Supplementary Information); ${ }^{13} \mathrm{C}$ NMR (100 MHz, dimethyl sulfoxide- $\left.d_{6}\right): \delta 151.5$ (C-2), 164.3 (C-4), 100.2 (C-5), 142.2 (C-6; Supplementary Information); electron ionization MS $\mathrm{m} / \mathrm{z}$ (rel. int.): $114[\mathrm{M}]^{+}(2), 112[\mathrm{M}-2 \mathrm{H}]^{+}(100), 78$ (18), 69 (49), 68 (18), 64 (16), 63 (22); high-resolution electron ionization MS m/z: $113.9950[\mathrm{M}]^{+}$(calcd for $\left.\mathrm{C}_{4} \mathrm{H}_{2} \mathrm{O}_{4}, 113.9953\right)$.

The molecular ion peak at $m / z 114[\mathrm{M}]^{+}$obtained by highresolution electron ionization MS is in accordance with the molecular

${ }^{1}$ Chemical Biology Research Center, Korea Research Institute of Bioscience and Biotechnology, Daejeon, Korea; ${ }^{2}$ Diabetic Complications Research Center, Korea Institute of Oriental Medicine, Daejeon, Korea and ${ }^{3}$ DDLEACHE Co., Ltd, Cheonan, Korea

Correspondence: Dr I-D Yoo, Chemical Biology Research Center, Korea Research Institute of Bioscience and Biotechnology, 111 Gwahangno, Yuseong-gu, Daejeon 305-806, Korea. 
a<smiles>O=c1ccoc(=O)o1</smiles>

1

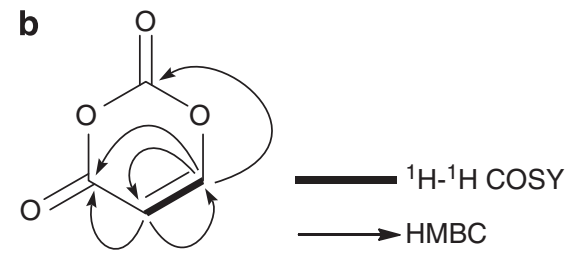

Figure 1 Chemical structure (a) and ${ }^{1} \mathrm{H}_{-}{ }^{1} \mathrm{H}$ COSY and $\mathrm{HMBC}$ correlations (b) of pleurone (1).

formula $\mathrm{C}_{4} \mathrm{H}_{2} \mathrm{O}_{4}$, indicating that $\mathbf{1}$ has a six-membered ring structure containing two oxygen atoms and four carbon atoms. Compound 1 also yielded a UV absorption peak at $258 \mathrm{~nm}$ and an IR band at $1714 \mathrm{~cm}^{-1}$, suggesting the presence of an $\alpha, \beta$-unsaturated lactone system. The ${ }^{1} \mathrm{H}-\mathrm{NMR}$ spectrum of 1 contained peaks at $\delta_{\mathrm{H}} 5.44$ $(\mathrm{d}, J=7.6 \mathrm{~Hz})$ and $\delta_{\mathrm{H}} 7.38(\mathrm{~d}, J=7.6 \mathrm{~Hz})$, indicating two olefinic protons. Analysis by ${ }^{13} \mathrm{C}$ NMR, combined with DEPT, revealed that 1 contains two $s p^{2}$ methine carbons (at $\delta_{\mathrm{C}} 100.2$ and 142.2) and two lactone carbonyl carbons (at $\delta_{\mathrm{C}} 151.5$ and 164.3). All protonated carbons and their protons were assigned by ${ }^{1} \mathrm{H}^{-}{ }^{1} \mathrm{H}$ COSY and HMQC experiments. The carbonyl carbons at $\delta_{\mathrm{C}} 151.5$ and 164.3 were assigned to C-4 and C-2, respectively, by an HMBC experiment showing long-range correlations between the carbon at $\delta_{\mathrm{C}} 151.5$ and $\mathrm{H}-6\left(\delta_{\mathrm{H}} 7.38\right)$, as well as between the carbon at $\delta_{\mathrm{C}} 164.3$ and H-5 $\left(\delta_{\mathrm{H}} 5.44\right)$ and H-6 $\left(\delta_{\mathrm{H}} 7.38\right)$ (Figure 1). On the basis of the above data, the structure of pleurone was established as $4 H$-1,3-dioxine-2, 4-dione (1).

Comparison of the physicochemical and spectral data for compounds 2, 3 and 4 with those in the literature identified these compounds as ergosterol (2), ${ }^{10}$ (24E)-3 $\beta$-hydroxycucurbita-5,24diene-26-oic acid $(3)^{11}$ and nicotinic acid (4). ${ }^{12}$ To the best of our knowledge, this is the first report of the constituents of $P$. eryngii var. ferulae.

The inhibitory activity of the isolated compounds 1-4 on HNE was evaluated according to a previously described procedure. ${ }^{13}$ Briefly, $100-\mu$ reactions containing $10 \mathrm{~mm}$ Tris- $\mathrm{HCl}$ buffer $(\mathrm{pH} 7.5), 1.4 \mathrm{~mm}$ MeO-Suc-Ala-Ala-Pro-Val-p-nitroanilide, 0.18 U HNE (EC 3.4.21.37, from Serva, Heidelberg, Germany), and various concentrations of sample were incubated in the wells of a 96-well plate for $2 \mathrm{~h}$ at $37^{\circ} \mathrm{C}$ in the dark. Each reaction was stopped by the addition of $100 \mu \mathrm{l}$ of soybean trypsin inhibitor $\left(0.2 \mathrm{mg} \mathrm{m}^{-1}\right)$, and the absorbance at $405 \mathrm{~nm}$ was immediately measured using a microplate reader. Epigallocatechin gallate was used as a positive control. As shown in Table 1, all of the tested compounds except nicotinic acid (4) moderately inhibited HNE. The $\mathrm{IC}_{50}$ values for 1, 2, and 3 ranged from 49.4 to $61.5 \mu \mathrm{M}$; in contrast, the $\mathrm{IC}_{50}$ value for the positive control, epigallocatechin gallate, was $8.8 \pm 0.8 \mu \mathrm{m}$. Although pleurone exhibited a relatively low HNE-inhibitory activity compared with epigallocatechin gallate, it might be more useful as a new HNE inhibitor due to its relatively high water solubility and low MW.

To further characterize the HNE-inhibitory behavior of pleurone, kinetic studies were carried out in the same reaction medium in the presence of 0,30 or $100 \mu \mathrm{M}$ pleurone at substrate concentrations ranging from 0.25 to $1 \mathrm{~mm}$. Reactions were started by the addition of diluted substrate and recorded over a time interval of $10 \mathrm{~min}$. Estimations of the maximal velocity $\left(V_{\max }\right)$ and $K_{\mathrm{m}}$ were made according to Eisenthal and Cornish-Bowden. ${ }^{14}$ The kinetic data are shown as a Lineweaver-Burk plot in Figure 2. The oxidation of HNE

Table 1 HNE inhibitory activity of compounds isolated from the fruit bodies of $P$. eryngii var. ferulae

\begin{tabular}{lc}
\hline Compounds & $\mathrm{IC}_{50}(\mu \mathrm{M})^{\mathrm{b}}$ \\
\hline Pleurone (1) & $61.5 \pm 1.2$ \\
Ergosterol (2) & $49.4 \pm 2.3$ \\
(24E)-3ß-Hydroxycucurbita-5,24-diene-26-oic acid (3) & $59.1 \pm 3.5$ \\
Nicotinic acid (4) & $>100$ \\
EGCGc & $8.8 \pm 0.8$
\end{tabular}

Abbreviations: EGCG, epigallocatechin gallate; HNE, human neutrophil elastase. ${ }^{a}$ Results are expressed as means \pm s.d. $(n=3)$.

${ }^{\mathrm{b}} \mathrm{I}_{50}$ indicates the concentration $(\mu \mathrm{m})$ at which the inhibition percentage of HNE activity was $50 \%$, and the values were determined by regression analysis.

cPositive control.

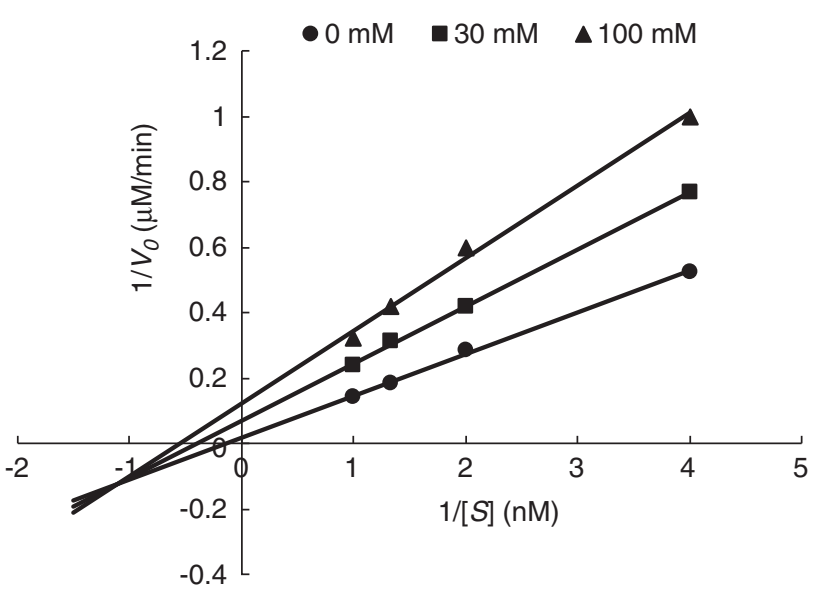

Figure 2 Lineweaver-Burk plot for inhibition of human neutrophil elastase by pleurone. The concentrations of pleurone were $0(\bullet), 30$ (घ) and $100 \mu \mathrm{m}(\mathbf{\Delta})$.

by pleurone followed Michaelis-Menten kinetics under the experimental conditions used. The intersection of the best-fit lines for the uninhibited enzyme and for the two different concentrations of pleurone occurs to the left of the $1 / V_{0}$ axis and below the $1 /[S]$ axis on the Lineweaver-Burk plot, indicating that both $K_{\mathrm{m}}$ and $V_{\max }$ decreased with increasing pleurone concentration. Thus, the inhibitory mechanism of pleurone on HNE is a mixed-type, a combination of noncompetitive and uncompetitive inhibition against HNE.

Despite its name, HNE has broad substrate specificity and can cleave not only elastin but also other extracellular matrix proteins, such as collagen, fibronectin, laminin and proteoglycan. ${ }^{15}$ Under normal physiological conditions, tissue repair after wounding requires the activity of elastase, which degrades foreign proteins within the extracellular matrix during phagocytosis. ${ }^{13}$ Because the pharmacologic inhibition of HNE might prevent the loss of skin elasticity, thus preventing skin sagging during aging, efforts to discover potent inhibitors of HNE have increased considerably in the last several years. These efforts have focused on natural products as a rich source of potential HNE inhibitors. Our findings suggest that $P$. eryngii var. ferulae and its components might be beneficial for the prevention or treatment of skin aging.

\section{ACKNOWLEDGEMENTS}

This work was supported by the National Research Foundation of Korea Grant funded by the Korean Government (MEST, NRF-2010-0022692). 
1 Wang, H. \& Ng, T. B. Isolation of a novel ubiquitin-like protein from Pleurotus ostreatus mushroom with anti-human immunodeficiency virus, translation-inhibitory and ribonuclease activities. Biochem. Biophys. Res. Commun. 275, 810-816 (2000).

2 Zusman, I. et al. Role of apoptosis, proliferating cell nuclear antigen and p53 protein in chemically induced colon cancer in rats fed corncob fiber treated with the fungus Pleurotus ostreatus. Anticancer Res. 17, 2105-2113 (1997).

3 Karacsonyi, S. \& Kuniak, L. Polysaccharides of Pleurotus ostreatus: isolation and structure of pleuran, an alkali-insoluble beta-D-glucan. Carbohydr. Polym. 24, 107-111 (1994).

4 Wang, W. S. \& Wang, D. H. Enhancement of the resistance of tilapia and grass carp to experimental Aeromonas hydrophila and Edwardsiella trada infections by several polysaccharides. Comp. Immunol. Microbiol. Infect. Dis. 20, 261-270 (1997).

5 Opletal, L. et al. Evidence for the anti-hyperlipidaemic activity of the edible fungus Pleurotus ostreatus. Br. J. Biomed. Sci. 54, 240-243 (1997).

6 Paulik, S. et al. The effect of fungal and yeast glucan and levamisole on the level of the cellular immune response in vivo and leukocyte phagocytic activity in mice. Vet. Med. 37, 675-685 (1992)

7 Kües, U. \& Liu, Y. Fruiting body production in basidiomycetes. Appl. Microbiol. Biotechnol. 54, 141-152 (2000).
8 Hong, K. H., Kim, B. Y. \& Kim, H. K. Studies on the biological activity of Pleurotus ferulea. J. Korean Soc. Food Sci. Nutr. 33, 791-796 (2004).

9 Choi, D. B., Cha, W. S., Kang, S. H. \& Lee, B. R. Effect of Pleurotus ferulae extracts on viability of human lung cancer and cervical cancer cell lines. Biotechnol. Bioprocess Eng. 9, 356-361 (2004).

10 Kwon, H. C., Zee, S. D., Cho, S. Y., Choi, S. U. \& Lee, K. R. Cytotoxic ergosterols from Paecilomyces sp. J300. Arch. Pharm. Res. 25, 851-855 (2002).

11 Tan, J. W., Dong, Z. J. \& Liu, J. K. New terpenoids from basidiomycetes Russula lepida. Helv. Chim. Acta 83, 3191-3197 (2000).

12 Fujioka, S. et al. Isolation and identification of nicotinic acid as a flower inducing factor in Lemna. Plant Cell Physiol. 27, 103-108 (1986).

$13 \mathrm{Kim}, \mathrm{Y}$. H. et al. Clitocybin D, a novel human neutrophil elastase inhibitor from the culture broth of Clitocybe aurantiaca. J. Microbiol. Biotechnol. 19, 1139-1141 (2009).

14 Eisenthal, R. \& Cornish-Bowden, A. The direct linear plot. A new graphical procedure for estimating enzyme kinetic parameters. Biochem. J. 139, 715-720 (1974).

15 Steinbrecher, T., Herenn, A., Dormann, K. L., Merfort, I. \& Labahn, A. Bornyl (3,4, 5-trihydroxy)-cinnamate-An optimized human neutrophil elastase inhibitor designed by free energy calculations. Bioorg. Med. Chem. 16, 2385-2390 (2008).

Supplementary Information accompanies the paper on The Journal of Antibiotics website (http://www.nature.com/ja) 